\title{
SOLUTION FOR RAW MATERIAL CRISIS IN BRICKS AND TILES MANUFACTURING INDUSTRIES
}

\author{
Shamimur Rahman ${ }^{1}$, Abdullah Al Mahmood ${ }^{2}$
}

\begin{abstract}
Ceramic industries in Bangladesh are using raw materials imported from abroad. For this reason, manufacturing costs of the ceramic products are quite high. Now a day, the demand of the ceramic products in Bangladesh is very high. To reduce the cost of these ceramic products, different types of local clays can be used as raw materials with quartz and feldspar to manufacture ceramic ware, tile, and sanitary ware. In this research, locally available clay of nine different areas had been used to prepare the sample. Their physical and mechanical properties were tested and studied to evaluate the quality of the products. Khagrachari (canal) and Padma (north) clay have shown better physical and mechanical properties. This clay is suitable for the production of ceramic ware and Khagrachari (Hill) and Padma (South) clay for quality tiles. The compositions of locally available clays were determined using X-Ray Fluorescence (XRF). XRF analysis showed the presence of excess $\mathrm{SiO} 2$ content in the form of Silicate, $\mathrm{Fe} 2 \mathrm{O} 3$, and $\mathrm{TiO} 2$ but the amount of $\mathrm{Al} 2 \mathrm{O} 3$ in most of the compositions was also not up to the minimum level. Observing the physical and mechanical properties, it is found that the local clay materials are suitable to use in ceramic industries by replacing the imported/traditional clay to reduce cost and make a perfect use of our natural resources.
\end{abstract}

Keywords - Clay, plasticity, density, Vickers hardness, ceramic products

\section{INTRODUCTION}

The ceramics is a class of inorganic, nonmetallic solids that are subjected to high temperature in the manufacture and use. The most common ceramics are composed of oxides, carbides, and nitrides. Silicides, borides, phosphides, tellurides, and selenides also are used to produce ceramics. Ceramic processing involves high temperatures, and the resulting materials are heat resistant or refractory [1-4]. The main ingredient of ceramic is different types of clay. Clay is a fine-grained natural rock or soil material that combines one or more clay minerals with traces of metal oxides and organic matter. Clays are plastic due to their water content and become hard, brittle and non-plastic upon drying or firing [5]. Geologic clay deposits are mostly composed of phyllosilicate minerals containing variable amounts of water trapped in the mineral structure [6-7].

Geological surveys indicated that Bangladesh has deposits of both residual and sedimentary types of clays. Some places across the country is better for the sources of various types of ceramic raw materials. Notable locations are Bijoypur in Mymensingh, Barapukuria, and Maddhyapara in Dinajpur, etc. The clays that are available in these sources are mainly China Clay, White Clay, Red Clay, Black Clay, Brick Clay, etc. [8]. In this paper, other than these clays, nine different clays from different sites of Bangladesh are characterized. Those locations are Khagrachari (canal), Khagrachari (hill), Khagrachari (plain land), Padma(south), Padma (north), Padma (river), Isamoti (ataikula), Isamoti (bera), Isamoti (pabna). The aim of the research is the study of chemical composition, physical properties and mechanical properties of the ceramic product and their firing behavior.

\section{MATERIALS AND METHODS}

When using the local clay, clay refining is an important and first step of methodology. 2 kilograms of clay lumps were crushed into small size particles by crusher machine. Then crushed particles were soaked in water for about a week. In the soaked clay, heavier and fine particles were formed in a suspension with some impurities. The clay suspension was washed through a sieve ASTM-200. Then larger size particles were separated and fine particles were

\footnotetext{
${ }^{1}$ Department of Glass \& Ceramic Engineering Rajshahi University of Engineering \& Technology, Rajshahi-6204, Bangladesh

${ }^{2}$ Department of Glass \& Ceramic Engineering Rajshahi University of Engineering \& Technology, Rajshahi-6204, Bangladesh
} 
mixed with the water in the final slurry. Also, a magnetic separator was used to separate the magnetic particles in the mixture. The final mixture was dried in the sun for initial drying. Finally, it was dried in a dryer for 24 hours to get fine clay particles.

Table 1 shows the batch composition of different clay. In the mixture feldspar was used 30\%, quartz 30\%, and different types of clay was used $40 \%$. Small amount of molasses was used as binding agent.

Table 1: batch composition

\begin{tabular}{|l|c|c|c|c|}
\hline \multicolumn{1}{|c|}{ Batch of different clay } & $\begin{array}{c}\text { Feldspar } \\
(\mathrm{wt} \%)\end{array}$ & $\begin{array}{c}\text { Quartz } \\
(\mathrm{wt} \%)\end{array}$ & $\begin{array}{c}\text { Local clay } \\
(\text { wt } \%)\end{array}$ & $\begin{array}{c}\text { Water } \\
\text { (wt\% of batch) }\end{array}$ \\
\hline Khagrachari (Canal) & 30 & 30 & 40 & $60 \%$ \\
\hline Khagrachari (Hill) & 30 & 30 & 40 & $60 \%$ \\
\hline Khagrachari (Plain land) & 30 & 30 & 40 & $60 \%$ \\
\hline Padma (South) & 30 & 30 & 40 & $60 \%$ \\
\hline Padma (North) & 30 & 30 & 40 & $60 \%$ \\
\hline Padma (River) & 30 & 30 & 40 & $60 \%$ \\
\hline Isamoti (Ataikula) & 30 & 30 & 40 & $60 \%$ \\
\hline Isamoti (Bera) & 30 & 30 & 40 & $60 \%$ \\
\hline Isamoti (Pabna) & 30 & 30 & 40 & $60 \%$ \\
\hline
\end{tabular}

Each composition was subjected to ball milling for 20 hours to get fine particles. Then it was dried at room temperature. The particles size is an important criterion for the quality of the product. The mixture was grinded to fine powder to achieve particles size less than 200 meshes. At this stage the powder was mixed with small amount of molasses. The molasses is the waste product of sugar mills available in local area. The mixture was then wrapped in polythene to prevent moisture loss or absorb. After a week the mixture was ready to prepare the samples. Several square shaped samples $(50 \mathrm{~mm} \times 50 \mathrm{~mm} \times 10 \mathrm{~mm})$ were prepared at a pressure 250 bars using a hydraulic press. The pressure used to achieve compact shaped samples. The green samples were first dried in open air for 2 hours. Then it was dried in an oven at $110{ }^{\circ} \mathrm{C}$. Finally, it was fired at three different temperatures $\left(1050{ }^{\circ} \mathrm{C}, 1100{ }^{\circ} \mathrm{C}\right.$, and $\left.1150{ }^{\circ} \mathrm{C}\right)$ to see the effect of sintering temperature. The soaking period was 90 minutes. A flow diagram of the abovementioned preparation procedure is shown in Fig 1.

Plasticity was measured according to Pfefferkorn is based on the principle of impact deformation [9]. Density was measured by the general formula of the ratio of mass and volume [10]. The Vickers hardness (HV) was measured by vicker indention technique [11].

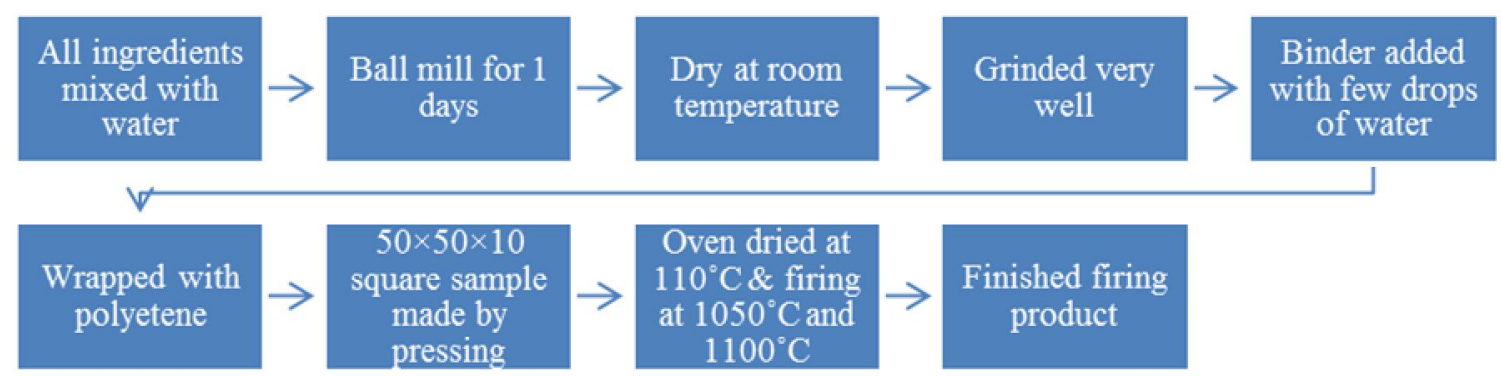

Fig. 1: Flow diagram of tile samples preparation

\section{RESULTS AND DISCUSSIONS}

Fig 2-4 represents the XRF patterns of several clays used in the analysis. Table 2 summarizes the elements found in the analysis of different clays. In the analysis, $\mathrm{SiO}_{2}$ found the maximum percentage in all the samples. Aluminium oxide $\left(\mathrm{Al}_{2} \mathrm{O}_{3}\right)$ was the second highest amount for the samples where other elements like $\mathrm{TiO}_{2}$, iron oxide, and other components found in the analysis in small percentage.

Khagrachari (canal) clays (fig 2) are kaolinite rich clay than other eight local clays. The initial color of the clay is reddish black but after drying the color seems like light ash. It contains higher amount of alumina of $25.13 \%$, silica 
$57.91 \%$ and $6.45 \%$ iron. The main source of this clay is hill canals, so the moisture content of the clay is very high, $16.13 \%$. Khagrachari (canal) Clay has plasticity factor about $2.5 \%$ and shows plastic behavior. The density of the clay sample is around 1.6-1.8\%. After preparing the sample with this clay different type of physical and mechanical test was done and they showed very good result.

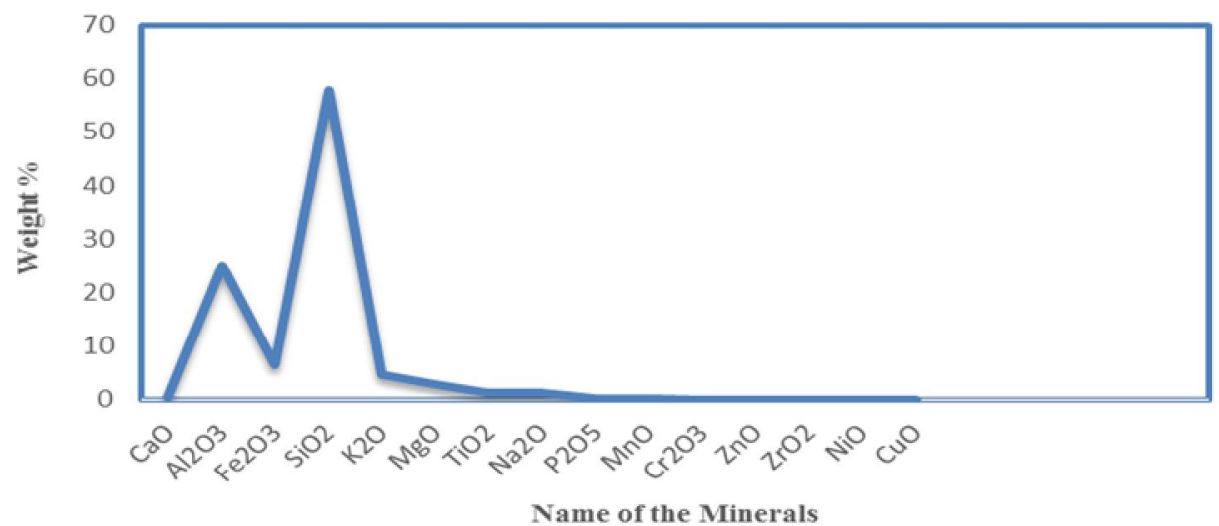

Fig 2: XRF analysis of Khagrachari (canal) clay

Padma (North) clay (Fig 3) contains $17.70 \%$ of alumina, 52.65\% of silica and around $8 \%$ of iron content. The main source of the clay is the bank of the Padma River. Other major constituent of this clay is $\mathrm{CaO} 9.24 \%, \mathrm{~K}_{2} \mathrm{O} 5.13 \%$. The color of this clay is deep gray. The density of the clay sample is $1.75-1.83 \%$. The moisture content of the clay is, $12.81 \%$. Padma (North) clay has plasticity factor about $3.07 \%$ and shows plastic behavior.

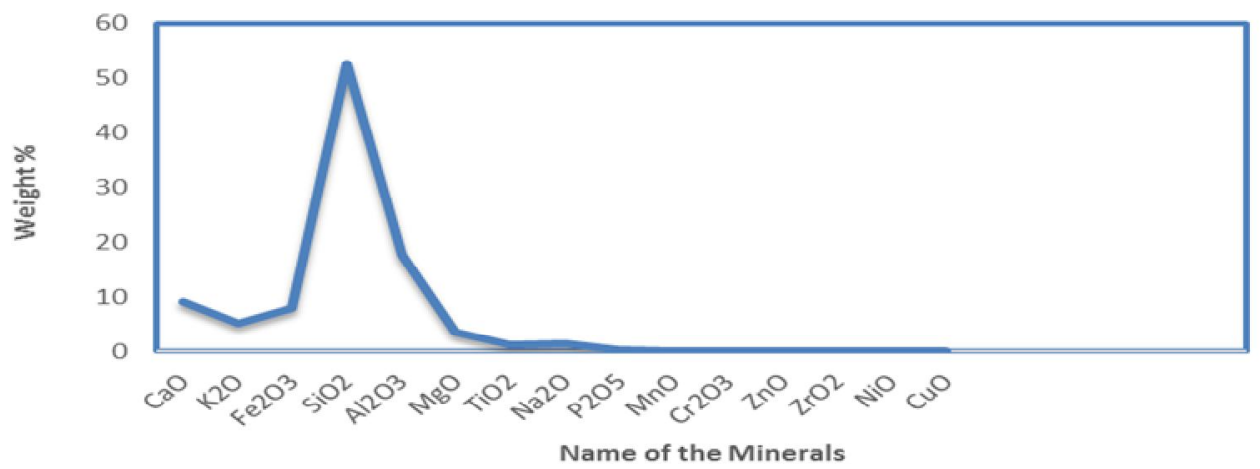

Fig 3: XRF analysis of Padma (north) clay

The Padma (river) clay (fig 4) contains $12.11 \%$ of alumina and around $6 \%$ of iron content. The color of the clay is light gray. The density of the clay sample is $1.70 \%$. Padma (river) clay has plasticity factor about $3.48 \%$ and shows plastic behavior.

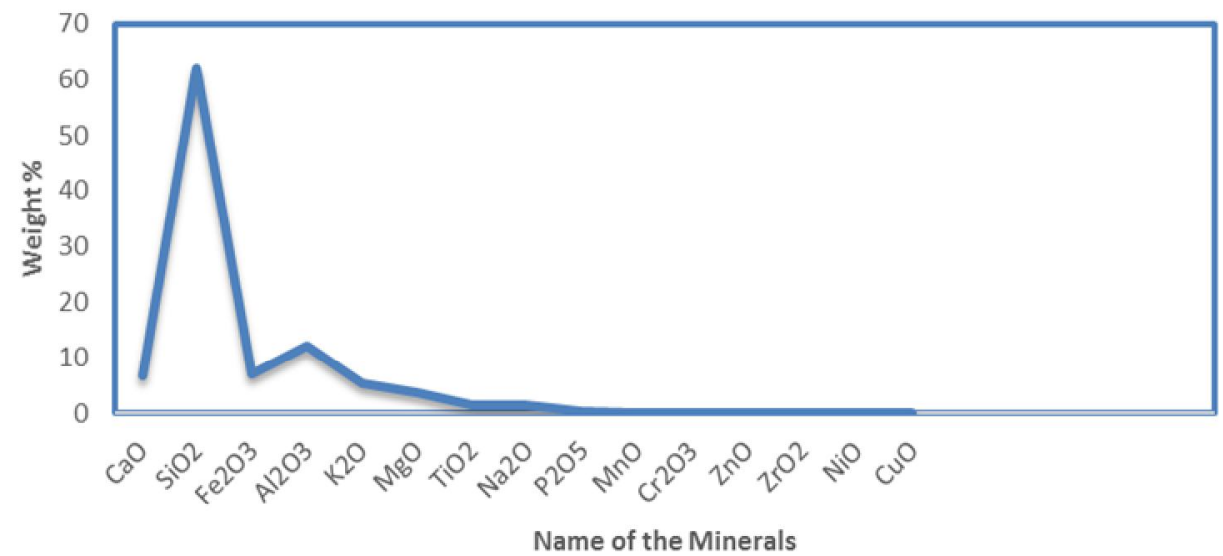

Fig 4: XRF analysis of Padma (river) clay 
In reference to the data, in Table 2, a comparison of local clay to imported material (standard compositions) would make obvious that the indigenous material is much higher in $\mathrm{SiO}_{2}, \mathrm{Fe}_{2} \mathrm{O}_{3}$ and $\mathrm{TiO}_{2}$ content and falling short in $\mathrm{Al}_{2} \mathrm{O}_{3}$ content. Typically, majority of Silica stay in free form as Quartz. Rest of the Silica content are associated with Alumina in bonded form, which forms phases like Kaolinite, Halloysite etc. Moreover, amount of impurities like $\mathrm{Fe}_{2} \mathrm{O}_{3}$ and $\mathrm{TiO}_{2}$ are also high in most of the local clay types.

Table 2: XRF analysis of locally available clay and imported clay

\begin{tabular}{|c|c|c|c|c|c|c|c|c|c|c|c|}
\hline 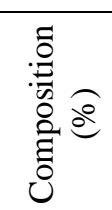 & 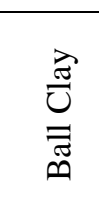 & $\begin{array}{l}\frac{\vec{\Xi}}{0} \\
\stackrel{\Xi}{\Xi} \\
\text { U] }\end{array}$ & 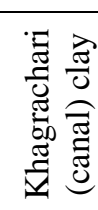 & 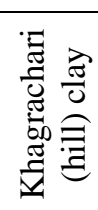 & 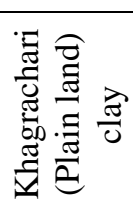 & 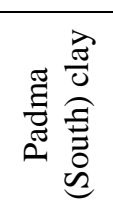 & 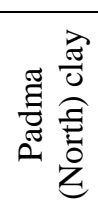 & 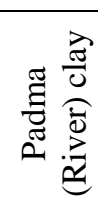 & 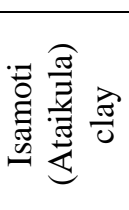 & 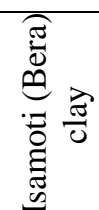 & 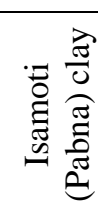 \\
\hline $\mathrm{SiO}_{2}$ & 44.63 & 50.18 & 57.91 & 65.96 & 69.91 & 55.00 & 52.64 & 62.01 & 57.60 & $\overline{62.61}$ & 59.65 \\
\hline $\mathrm{Al}_{2} \mathrm{O}_{3}$ & 36.93 & 33.34 & 25.13 & 22.28 & 13.13 & 19.11 & 17.90 & 12.11 & 15.55 & 11.92 & 10.90 \\
\hline $\mathrm{Fe}_{2} \mathrm{O}_{3}$ & 0.96 & 1.88 & 6.44 & 4.40 & 6.92 & 6.99 & 7.96 & 7.01 & 8.61 & 8.62 & 8.42 \\
\hline $\mathrm{TiO}_{2}$ & 3.57 & 0.01 & 1.33 & 1.14 & 1.16 & 1.18 & 1.27 & 1.39 & 1.26 & 1.15 & 1.20 \\
\hline Others & 13.91 & 14.59 & 9.17 & 6.19 & 8.88 & 17.69 & 20.20 & 17.48 & 16.95 & 15.70 & 19.83 \\
\hline
\end{tabular}

Physical and mechanical characteristics were considered to examine the quality of the products. Tiles of nine different clays were prepared, and their physical properties such as plasticity density and hardness were tested to evaluate the quality of the products.

Plasticity depends on composition, particle size, organic matter and additives. Fig 5 shows the highest plasticity factor 3.48\% of Padma (river) clay than others and it excluded the normal value. Most of the clays except Khagrachari (Canal),Khagrachari (Plain land) show plasticity value between the standard ranges so they shows plastic behaviour. Khagrachari (Canal) clay shows $2.5 \%$ plasticity and Khagrachari (Plain land) clay shows 2.25\% plasticity. So they show non plastic behavior.

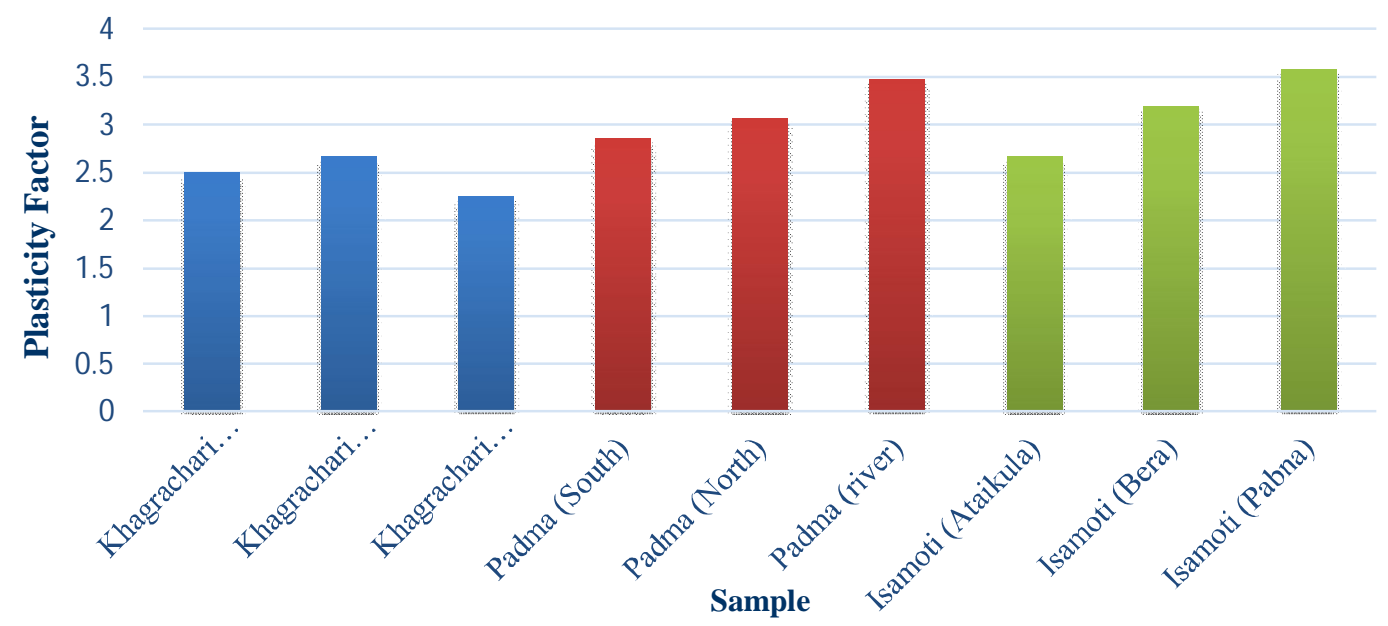

Fig 5: Plasticity of different clays

Density depends on composition, particle size, organic matter and additives. The density of the samples increases with the increase of temperature. Fig 6-8 represents the density of different clays at three different temperatures. Density is found to be very low at $1050^{\circ} \mathrm{C}$ and high degree of density is obtained at $1100^{\circ} \mathrm{C}$ and $1150^{\circ} \mathrm{C}$. Khagrachari (Canal), Khagrachari (Hill), Padma (North) shows maximum density at $1100^{\circ} \mathrm{C}$ than other clays. At $1150^{\circ} \mathrm{C}$ density of these clays increases much but at this temperature the sample fails or cracks. 


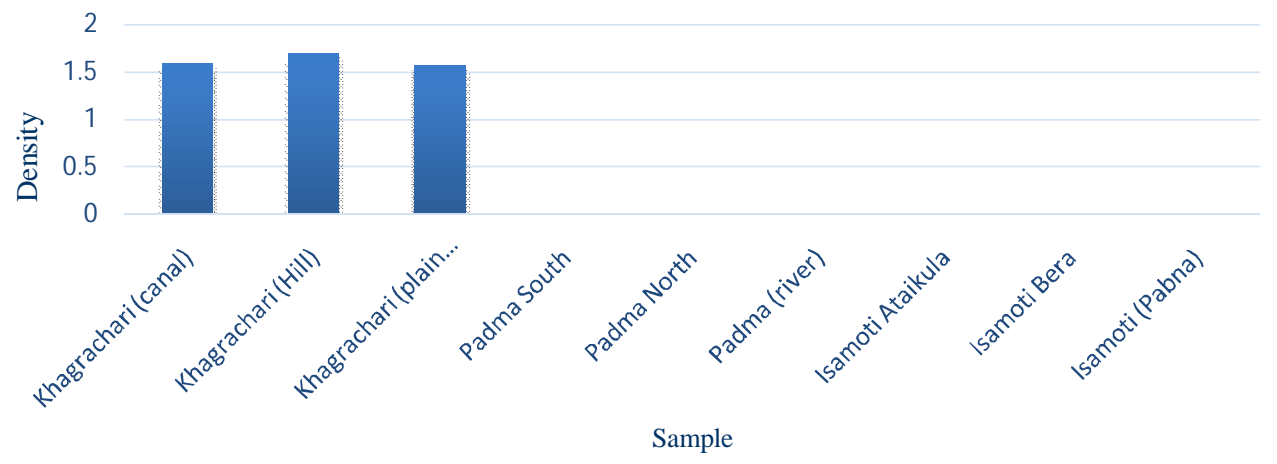

Fig 6: Density of different tile samples fired at $1050^{\circ} \mathrm{C}$

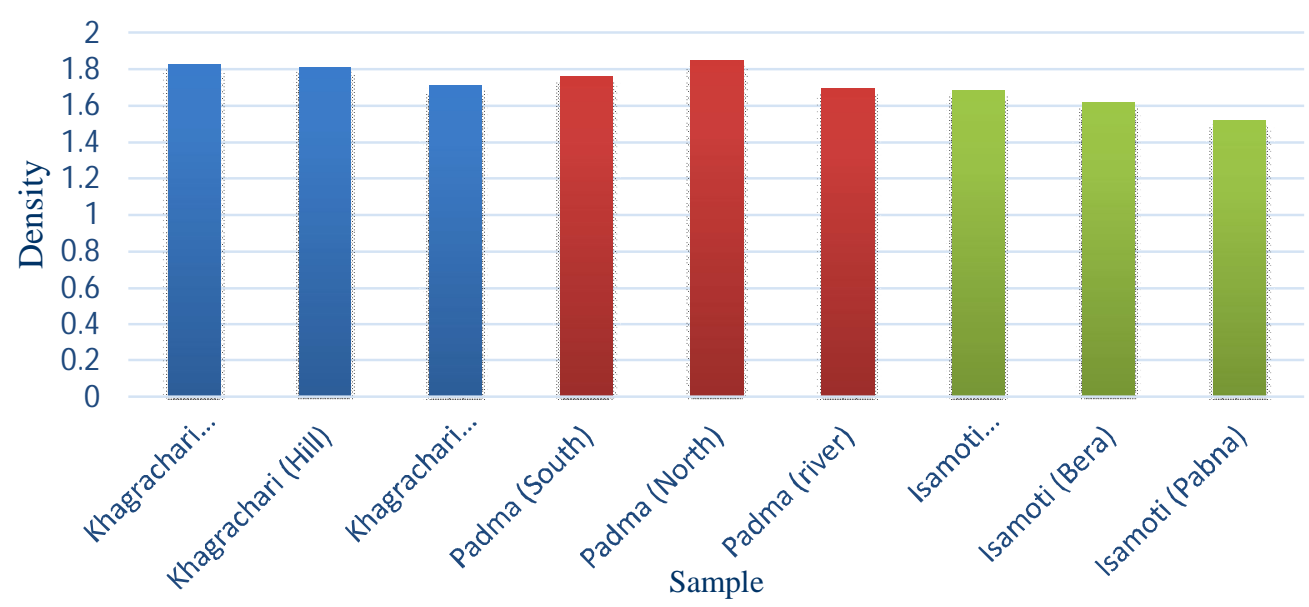

Fig 7: Density of different tile samples fired at $1100^{\circ} \mathrm{C}$

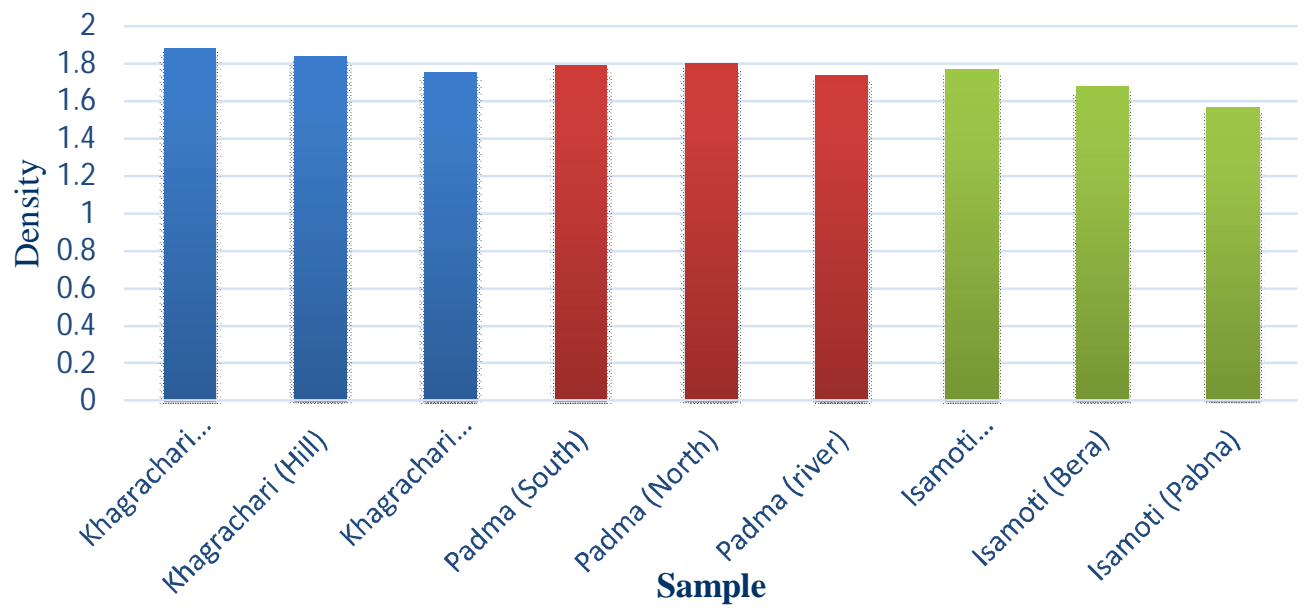

Fig 8: Density of different tile samples fired at $1150^{\circ} \mathrm{C}$

Fig 9-11 represent the vicker's hardness of different clays at three different temperatures. At both $1100^{\circ} \mathrm{C} \& 1150^{\circ} \mathrm{C}$ Padma (South) and Padma (North) clay shows hardness about 5.63 GPa and 5.98 GPa respectively and it is much 
higher than others. The Vickers hardness value for ceramic product lies between 10-30 GPa and for ceramic tile the range vary between $5-10 \mathrm{GPa}$.

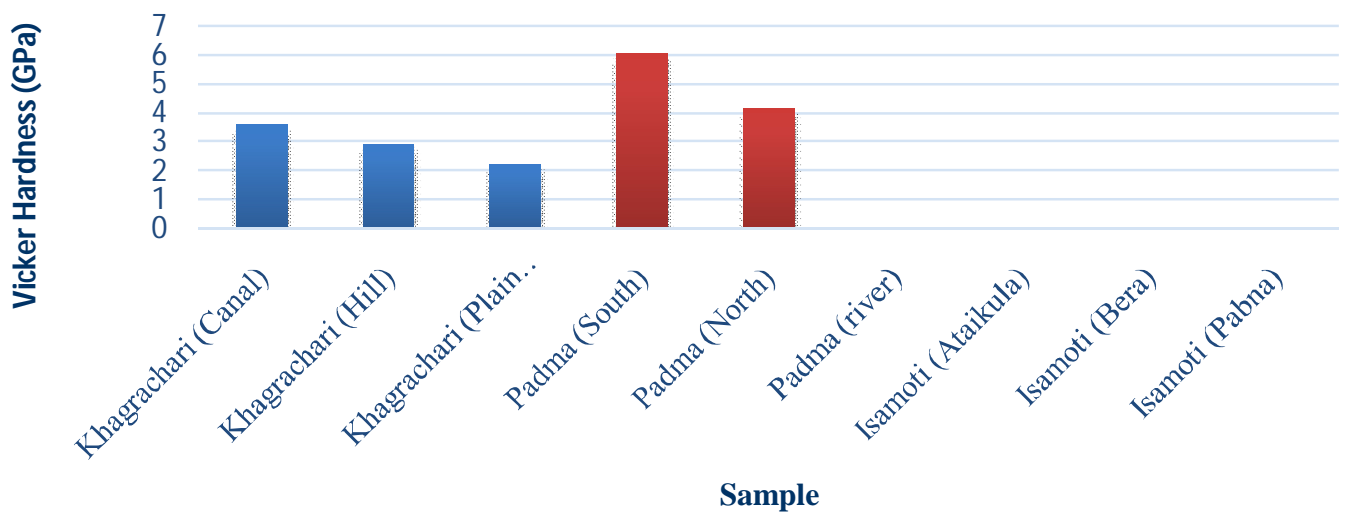

Fig 9: Hardness of different tile samples fired at $1050^{\circ} \mathrm{C}$

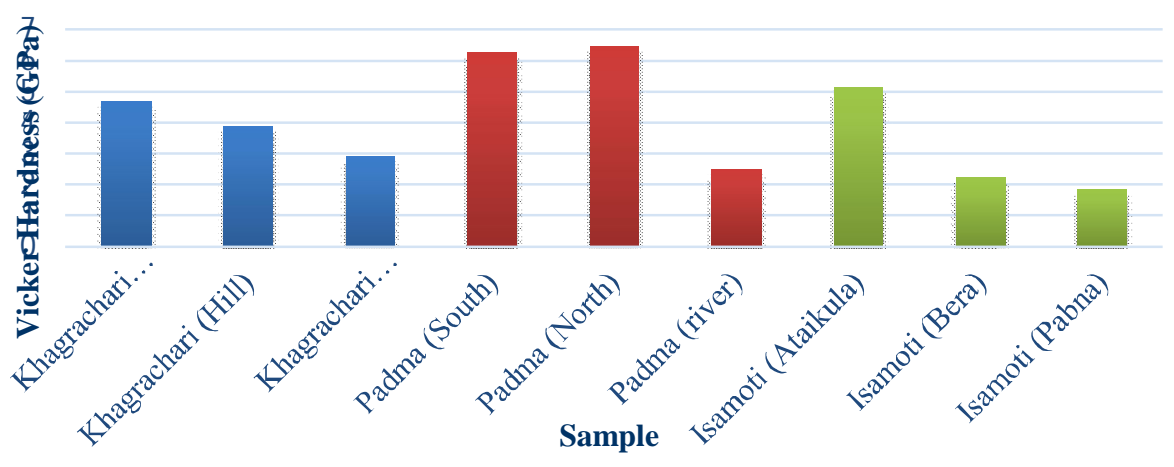

Fig 10: Hardness of different tile samples fired at $1100^{\circ} \mathrm{C}$

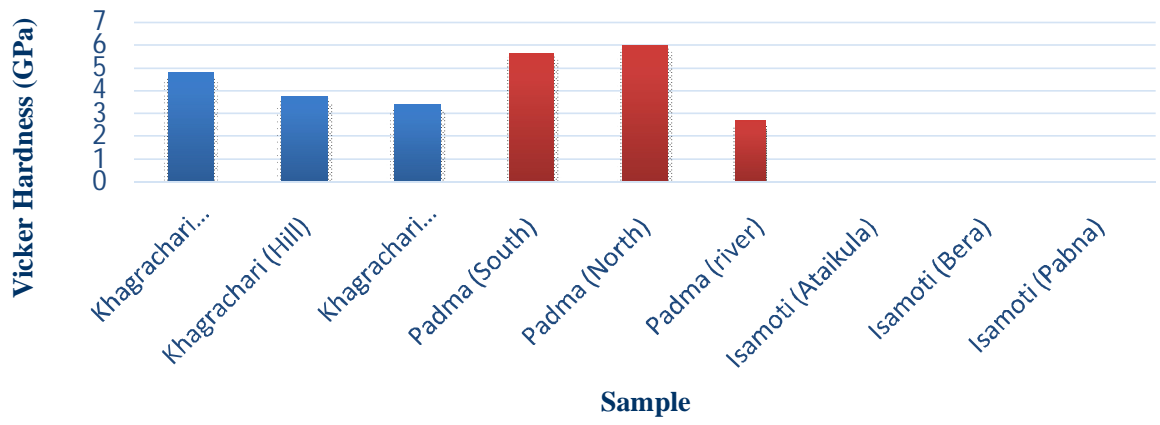

Fig 11: Hardness of different tile samples fired at $1150^{\circ} \mathrm{C}$ 
Table 3: Physical and mechanical properties of prepared samples and comparison with commercial standard (For $1100{ }^{\circ} \mathrm{C}$ )

\begin{tabular}{|c|c|c|c|c|c|c|c|c|c|c|}
\hline 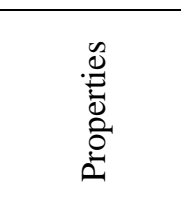 & $\frac{\alpha}{\frac{\alpha}{\alpha}}$ & 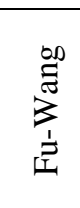 & 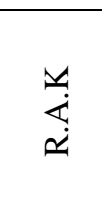 & 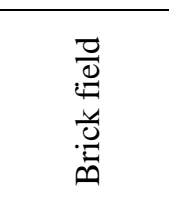 & 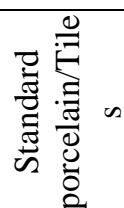 & 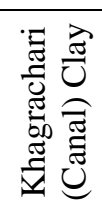 & 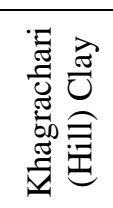 & 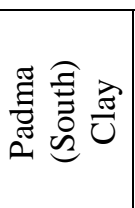 & 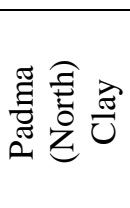 & 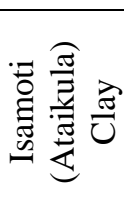 \\
\hline Density & 1.76 & 1.54 & 1.68 & $1.03-1.5$ & - & 1.83 & 1.81 & 1.76 & 1.85 & 1.69 \\
\hline $\begin{array}{l}\text { Water } \\
\text { absorption }\end{array}$ & $8-10$ & 16.7 & 12.10 & $20-22$ & - & 14.41 & 11.22 & 12.69 & 9.20 & 10.61 \\
\hline Porosity & $10-12$ & 27.0 & 20.68 & 38.16 & - & 16.35 & 11.85 & 15.18 & 12.41 & 12.40 \\
\hline Hardness & - & - & - & $1.765-2.55$ & $5-10$ & 4.7 & 3.88 & 6.26 & 6.49 & 5.13 \\
\hline $\begin{array}{l}\text { Compressiv } \\
\text { e strength }\end{array}$ & - & - & - & $1.9-10.8$ & $50-60$ & 51.46 & 48.09 & 50.82 & 54.26 & 44.92 \\
\hline
\end{tabular}

Table 3 shows the comparison of physical and mechanical properties of the finished products with the properties of commercially available tiles of several ceramic industries (Farr, Fu-Wang and, R.A.K) These values are collected from the respected factories. Table 3 shows the comparison of physical properties such as density, water absorption, porosity, hardness, and compressive strength with the standard values

\section{CONCLUSION}

The motive of this investigation was to reduce the cost of producing ceramic ware and to ensure the proper utilization of local clay resources. The compositions of locally available clay are determined by using X-Ray Fluorescence (XRF). Due to high percentages of impurity content in local clay, these clays are refined. The samples were made by the traditional method of tiles production using hydraulic press machine. In the experiment nine different types of local clay samples and three different temperatures $\left(1050^{\circ} \mathrm{C}, 1100^{\circ} \mathrm{C}\right.$, and $\left.1150^{\circ} \mathrm{C}\right)$ were used. The physical and mechanical properties of the produced tiles at $1100^{\circ} \mathrm{C}$ was close to the properties of commercially available tiles. So $1100^{\circ} \mathrm{C}$ is the optimum temperature for these local clays. Then some basic physical and mechanical properties such as firing shrinkage, water absorption, density, bending strength, compressive strength, hardness had been tested and recommended as bellows.

$>$ Khagrachari (canal) clay - ceramic ware and quality tiles.

$>$ Khagrachari (hill) clay - quality tiles.

$>$ Khagrachari (plain land) clay - low quality tiles and brick field.

$>$ Padma (south) clay - quality tiles.

$>$ Padma (north) clay - ceramics wares and quality tiles.

$>$ Padma (river) clay - pottery and bricks.

$>$ Isamoti (ataikula) clay - bricks and pottery.

$>$ Isamoti (bera) clay - tiles.

$>$ Isamoti (pabna) clay - bricks and pottery.

\section{REFERENCES}

[1] www3.epa.gov/ttnchie1/ap42/ch11/final/c11s07.pdf

[2] Kirk-Othmer. Encyclopedia of Chemical Technology, Fourth Edition, Volume 5, John Wiley \& Sons, New York, 1992

[3] 1987 Census of Manufactures, U. S. Department of Commerce, Washington, D.C., May 1990.

[4] Ullman's Encyclopedia of Industrial Chemistry, Fifth Edition, Volume A6.

[5] Guggenheim \& Martin 1995, pp. 255-256

[6] "University College London Geology on Campus: Clays". Earth Sciences department. University College London. Retrieved 10 January 2016.

[7] "What is clay". Science Learning Hub. University of Waikato. Retrieved 10 January 2016. 
[8] Adnan Mousharraf, Md. Sazzad Hossain, Md. Fakhrul Islam. (2011), "Potential of Locally Available Clay as Raw Material for Traditional-Ceramic Manufacturing Industries", Journal of Chemical Engineering, IEB Vol. ChE. 26, No. 1, December 2011. www.banglajol.info/index.php/JCE/article/

[9] Plasticity and geophysical flows: a review,C. Ancey, J. Non Newtonian Fluid Mech., 142 (1-3) (2007), pp. 4-35

[10] S. Maity, A. Kumar, B.K. Sarkar, Role of nucleating agents in the development of high strength porcelain, CFI-Berder DKG 70 (9) (1993) 483-490.

[11] George D.Quinn, Hardness testing of ceramics, 1998, vol.154,edition2,page 45 